Удк 94(57).084.9

ББК 63.3(2)

\title{
МЭРЫ И УГОЛОВНЫЙ КОДЕКС: ТИПОЛОГИЯ НАКАЗАНИЙ И МОТИВЫ ВЛАСТИ (НА ПРИМЕРЕ ИРКУТСКОЙ ОБЛАСТИ)
}

Анализируется типология преступлений, в которых обвинялись руководители муниципальных образований Иркутской области в 2000-2010-х гг. Предпринята попытка определить: носят ли уголовные дела заказной и политический характер.

Ключевые слова: мэры, уголовное преследование, коррупция, взятка, политические партии.

E.N. VOLOSOV

\section{THE MAYORS AND THE CRIMINAL CODE: A TYPOLOGY OF PUNISHMENT AND THE MOTIVES OF THE AUTHORITIES (EXAMPLE OF IRKUTSK REGION)}

The typology of crimes in which heads of municipalities of the Irkutsk region in 2000-2010-ies were accused is analyzed. An attempt has been made to determine whether criminal cases are of a registered and political nature. parties.

Keywords: mayors, criminal prosecution, corruption, bribe, political

За последние десять лет в стране значительно увеличилось количество мэров, депутатов, высокопоставленных представителей исполнительной власти, привлеченных к суду за совершение уголовных преступлений. Не обошла эта кампания и Иркутскую область. Начиная с 2009 г. уголовному преследованию подверглись около десятка руководителей муниципальных образований, среди которых самые крупные города региона: Братск, Ангарск, Усть-Илимск, Усолье-Сибирское, Иркутский и Казачинско-Ленский районы.

Задача нашего исследования: дать типологию преступлений, в которых обвинялись руководители муниципальных образований, попытаться определить: носят ли данные уголовные дела заказной и, возможно, политический характер. 
Мэр любого без исключения российского города не может позиционировать себя чистым хозяйственником. Это всегда политическая фигура, которой требуется выстраивать взаимоотношения со множеством субъектов экономической, политической, социальной, культурной, образовательной и даже криминальной деятельности.

Бэкграунд типичного мэра: 1) владелец среднего или крупного бизнеса, решивший его расширить с помощью административного ресурса; 2) менеджер среднего уровня градообразующего предприятия, входящего в один из холдингов федерального уровня и поддерживаемый всей финансовой и политической мощью компании; 3) несистемный популист, искренне верящий в то, что сможет управлять муниципальным хозяйством лучше, чем его предшественники и победивший на волне эгалитарных и антикоррупционных настроений избирателей; 4) высокопоставленный чиновник регионального или муниципального уровня, получивший «карт-бланш» от местного и регионального руководства правящей партии на участие в выборах мэра.

После отмены в ряде центров регионов прямых выборов мэра перестал быть актуальным только третий персонаж.

В том, что именно мэры оказываются чаще всего под пристальным вниманием правоохранительных органов, есть вполне объективные причины.

Чем располагает мэр любого, самого депрессивного муниципального образования? 1) Административным ресурсом, позволяющим допускать к бюджетному фринансированию «определенных» предпринимателей. 2) Финансовым ресурсом, позволяющим в определенных обстоятельствах, напрямую оплачивать услуги и товары, поставляемые субъектам в муниципальном образовании. 3) Возможностями по распределению земельных участков, передаче в аренду муниципальной недвижимости. 4) Кадровым ресурсом, дающим возможность устраивать на должности муниципальных служащих, не только по деловым качествам, но и в силу иных обстоятельств, лежащих за пределами классического кадрового менеджмента.

Почему в рамках современного российского законодательства мэр остается практически беззащитным перед возможным произволом правоохранительных органов? 1) Отсутствие иммунитета, которым обладают депутаты представительных органов. 2) Отсутствие в бюджете муниципального образования ресурсов, необходимых для ведения нормальной хозяйственной деятельности поселения. Отсюда, широко распространенная практика фрактического вымогательства средств на муниципальные нужды у предпринимателей. 3) Наличие конкурентов в борьбе за ресурсы, имеющих обязательную поддержку в одном из правоохранительных ведомств и ждущих явных ошибок мэра.

Под приведенные выше признаки подпадают все нашумевшие уголовные дела, заведенные на мэров муниципальных образований 
Иркутской области, не исключая мэров г. Усть-Илимска В.В. Дорошка и г. Усолье-Сибирское Е.С. Кустоса, осужденных за организацию и подстрекательство к заказному убийству.

Наиболее популярная статья Уголовного кодекса РФ, по которой сажали мэров муниципальных образований Иркутской области, это статья 290 части 4 и 6 (получение взятки и взятки в особо крупном размере) в особо крупном размере). Подобное обвинение было предъявлено мэрам гг. Братска А.В. Серову и Усть-Илимска В.С. Ташкинову, мэру Казачинско-Ленского района А.С. Абраменко.

Данное обвинение, с одной стороны трудно доказуемое, с другой легко инкриминируемое. Человек мог оказаться обвиняемым даже без материальных доказательств, вроде помеченных купюр, аудио или видеоматериалов, подтверждающих фракт мздоимства. Вся доказательная база выстраивается на признании взяткодателя, предположения следственных органов на основании косвенных улик о том, что мэр получил незаконное «вознаграждение» за решение какой-либо проблемы в пользу взяткодателя.

Наиболее неоднозначным выглядело уголовное дело, заведенное в отношении мэра г. Усть-Илимска В.С. Ташкинова. В июне 2017 г. Усть-Илимским городским судом мэру был вынесен приговор в виде лишения свободы сроком 11 лет и штрафом в 30 млн р. за получение «взяток в виде денег за способствование в силу должностного положения совершению действий в пользу взяткодателя Скрипцова А.А.». Общая сумма взяток по мнению следствия и признанная судом составила 11 млн р. [12].

Интересно, что суд не установил сам фракт получения мэром взятки, в приговоре отсутствуют объективные и достоверные доказательства. Не установлен предмет взятки, так как не изъяты денежные средства, не смогли быть установлены фракты расходования денег обвиняемым или членами его семьи; не представлены видеоматериалы, подтверждающие передачу денежных средств, нет заключений судебных экспертиз. В деле отсутствовали сведения о давлении мэра на организации, подконтрольные взяткодателю А.А. Скрипцову. По сути, вся обвинительная база выстроилась только на показаниях одного человека - хозяина фрирмы «РегионСпецТранс» А.А. Скрипцова, выигравшего аукционы на ремонт и обслуживание дорог в Усть-Илимске.

Впечатляет и несоизмеримость наказания: 11 лет колонии строго режима за 11 млн взятки при весьма сомнительных доказательствах. Причины подобной сверхжесткой оценки возможных деяний В.С. Ташкинова могут быть объяснены несколькими причинами. 1) Категорический отказ мэра Усть-Илимска с обвинением в получении взятки. 2) Конфликт мэра с тогдашним губернатором области С.В. Ерощенко, стремившимся взять под свой контроль новое предприятие города - завод ОСБ и встретив- 
шего сопротивление со стороны В.С. Ташкинова. 3) По мнению адвоката М. Черкашиной, защищавшей мэра, у суда был явно обвинительный уклон. Он не усомнился ни в одном документе, ни в одном из показаний свидетелей А. Невмержицкого и А. Скрипцова, на основе которых и выдвинуто обвинение. Адвокат считал, что действия судьи логично вписываются в действия судов в последние годы, когда оправдательные приговоры насчитывают лишь 0,02 \% [10]. 4) На выборы мэра В.С. Ташкинов выдвигался, будучи членом партии «Справедливая Россия», и лишь потом по каким-то причинам вышел из нее и вступил в «Единую Россию». По версии известной право-защитницы, ныне покойной Людмилы Алексеевой, с 2007 г. в России проводился целый «ряд спецопераций против оппозиционных мэров» [8]. Главы городов, победившие на выборах кандидатов от «Единой России», подвергаются уголовному преследованию и отстраняются от должности под надуманными предлогами. И даже переход из оппозиционной партии в правящую, не дает иммунитета. Вполне вероятно, что усть-илимский мэр мог оказаться жертвой этого негативного тренда.

Еще более странной, напоминающей сюжет из ироничного детектива, выглядела история с арестом и наказанием мэра г. Братска А.В. Cерова. Последний победил на выборах мэра в мае 2010 г. как кандидат от КПРФ. Менее чем через год, 2 февраля 2011 г. А.В. Серова задержали в собственной квартире, расположенной в обычной панельной девятиэтажке. Полтора часа следователи уговаривали мэра открыть дверь квартиры. По версии правоохранителей все это время Серов, пытался избавиться от доказательств и сжигал один миллион 50 р. мелкими купюрами. Эти деньги были якобы получены в качестве взятки от А.Ю. Гаськова - руководителя фракции партии «Справедливая Россия» в Законодательном Собрании Иркутской области, на тот период владельца крупнейшей городской компании ЖКХ. В конечном итоге, дверь в квартиру вскрыли пилой по металлу - «болгаркой». О деньгах ходили курьезные легенды: то ли мэр сжег их, облив коньяком, то ли сложил в наволочку и выбросил в окно. В любом случае, ни во время следствия, ни в зале суда эти купюры не были предъявлены в качестве доказательств, что неизбежно выводит на вопрос: «А был ли мальчик?».

Потом было признание в вымогательстве взятки в размере 15 млн р. за продление договора на аренду полигона для сбора и переработки мусора компанией А.Ю. Гаськова, заявление об отставке с поста мэра, отказ от признания вины.

В защиту А.В. Серова выступил региональный лидер КПРФ С.Г. Левченко. Братские коммунисты и им сочувствующие обращались к президенту, главе правительства, генеральному прокурору, председателю Следственного комитета РФ, руководству ФСБ с призывом остановить беззаконие в отношении мэра г. Братска. Знаменательно, что письмо, 
адресованное президенту, передал в руки главы государства лично председатель КПРФ Г.А. Зюганов.

Протесты не помогли. По приговору Братского городского суда А.В. Серов был признан виновным в преступлении, предусмотренном ч. 4 ст. 290 УК РФ (получение взятки), и приговорен к пяти с половиной годам лишения свободы в колонии строгого режима без назначения штрафа [4]. В этом приговоре все достаточно странно. Если есть взятка в 15 млн р., почему достаточно мягкий размер наказания в сравнении с вердиктом суда в отношении В.С. Ташкинова и отсутствует штраф? Почему так и не были предъявлены вещественные доказательства или никак не объяснено их отсутствие?

Можно предположить, что в отношении мэра «северной» столицы области была разыграна сложная комбинация с участием правящей партии, администрации области и правоохранительных органов с целью жестко указать коммунистам на недопустимость претензий на любые посты в системе существующей власти. В отличие от мэров г. Усть-Илимска В.С. Ташкинова и г. Иркутска В.И. Кондрашова, после победы на выборах, оказавшихся в рядах «Единой России», А.В. Серов отказался от вступления в ряды правящей партии. По версии официального печатного органа КПРФ газеты «Советская Россия» «единороссы» не терпят нахождения у власти политических оппонентов [5].

Забавным и очень поучительным для избирателей являлся тот факт, что лицом, инициировавшим политический скандал, выступил видный представитель партии «Справедливая Россия» А.Ю. Гаськов. Тем самым, еще раз была показана роль этой общественно-политической организации, как спойлера КПРФ, фрактически работающего в интересах правящей партии.

В отличие от уголовных дел В.С. Ташкинова и А.В. Серова, предположительно имеющих характер политического или субъективного заказа, наказание других руководителей муниципальных образований Иркутской области не только отчетливо вписывалось в указанные в начале статьи признаки, но и носило вполне доказательный характер.

Например, мэр Казачинско-Ленского района А.С. Абраменко, в феврале 2019 г. судом признан виновным в совершении преступления, предусмотренного ч. 6 ст. 290 УК РФ (получение взятки в особо крупном размере) и приговорен к четырем годам колонии строгого режима. Следствие и суд установили, что в феврале 2017 г. А.С. Абраменко и его заместитель А.Л. Амосов получили часть взятки в размере 2,5 млн р. (общая сумма должна была составить 5 млн р.) от подрядчика, выполнявшего работы в рамках муниципального контракта по строительству полигона твердых бытовых отходов в Казачинско-Ленском районе [2].

Достаточно мутная история, в которой переплелись опять же политические и экономические интересы региональных и местных элит, 
произошла с бывшим мэром г. Ангарска В.В. Жуковым. Он был обвинен в растрате бюджетных средств (ч. 3 ст. 160 УК РФ). Суд приговорил В.В. Жукова к четырем годам условно с лишением права занимать выборные должности и должности на государственной службе и в органах местного самоуправления сроком на два года.

По версии следствия осенью 2012 г. В.В. Жуков, уходя досрочно с поста мэра Ангарского муниципального образования, заключил дополнительное соглашение с вице-спикером думы Светланой Кажаевой, в соответствии с которым она получила доплату за исполнение полномочий мэра в размере 1,3 млн р. Пикантности этому делу придают несколько фрактов. Факт первый - задержание мэра произошло за пределами России, в дружественной нам Белоруссии, откуда он был экстрадирован на родину. Почему мэр не спрятался в Лондоне, откуда «выдачи нет», не очень понятно. Возможно, и не прятался. Факт второй - сложное административное устройство, буквально провоцирующее на межвластные конфрликты. В декабре 2004 г. был принят Закон Иркутской области, по которому на территории Ангарского района и Ангарска появились Ангарское муниципальное образование со статусом городского поселения, собственно сам Ангарск и Ангарское муниципальное образование Иркутской области со статусом муниципального района. Таким образом, город Ангарск из субъекта области превратился в субъект района, приравненный к сельским поселениям. Третий фракт - латентный конфликт В.В. Жукова с тогдашним губернатором области В.В. Ерощенко, видевшим во главе Ангарского городского округа и г. Ангарска более лояльных и «послушных» персонажей [11]. Четвертый фракт — голодовка мэра и одиночный пикет осенью 2013 г. у здания ангарской прокуратуры, предшествовавшие заведению уголовного дела, аресту и приговору. Главной мишенью акции с участием В.В. Жукова стал прокурор г. Ангарска Д. Погудин. Таким экстравагантным образом мэр попытался выразить протест против якобы «прокурорского беспредела», творящегося в Ангарске и мешающего нормальной работе городских властей. Конфликт получил всероссийскую огласку, новость прозвучала на «Радио Свобода» и телеканале «Дождь». Лично прокурор в свое оправдание вынужден был обвинить В.В. Жукова фрактически в нецелевом использовании многомиллионых средств [3]. Впрочем, точная сумма ущерба, нанесенного бюджету г. Ангарска его мэром, Д. Погудиным озвучена не была.

Последовавшее за этим событием уголовное дело в отношении В.В. Жукова по вызывающей много вопросов сумме в 1,3 млн р. доплаты С. Кажаевой, относительно легкий приговор, показали, что обвинения прокуратуры в адрес мэра были лишены серьезной доказательной базы и носили больше публицистический, нежели правовой характер.

И, наконец, в Иркутской области живут два бывших мэра, обвиненных: один в организации убийства (В.В. Дорошок), другой - в подстре- 
кательстве к убийству (Е.С. Кустос). Однако мотивы этих двух резонансных дел имеют серьезные отличия.

Арест мэра г. Усть-Илимска В.В. Дорошка в 2007 г. и окончательный приговор в 2009 г. стали концом истории, произошедшей в далеком 1996 г. Именно тогда в декабре на пороге собственного дома был убит заместитель генерального директора ПО «Усть-Илимский лесопромышленный комплекс» А. Пуртов. Убийцы были оперативно найдены и арестованы, однако заказчика преступления они не выдали.

Уже тогда одним из предполагаемых заказчиков убийства называли руководителя АОЗТ «Ксилема», будущего мэра В.В. Дорошка, однако прямых улик следственные органы не нашли, а арестованные и признавшиеся в преступлении лица, заказчика не назвали [7]. Анализ архивных и газетных материалов позволяет сделать вывод, что убийство, инициированное В.В. Дорошком, совершалось не по экономическим причинам: свою собственность хозяин «Ксилемы» уже потерял безвозвратно. Вероятней всего в основе преступления лежал фактор мести. А. Пуртов, действительно, был наиболее активен в доведении «Ксилемы» до банкротства и отчуждении ее собственности в пользу ЛПК [9].

После выхода убийц из колонии, один из них О. Пихун, дал признательные показания против В.В. Дорошка. Следствие длилось с 2007 по 2009 г. Бывший мэр вину свою так и не признал. Прямых улик в отношении обвиняемого в заказном убийстве так и не было найдено. Обвинение строилось на свидетельствах исполнителей и экономических причинах конфликта между В. Дорошком и А. Пуртовым. В конечном итоге, обвиняемый был приговорен к девяти годам лишения свободы с отбыванием наказания в колонии строгого режима. Наказание, с учетом СИЗО истекало в 2017 г. Однако на свободу В.В. Дорошок вышел по УДО в 2013 г. Сначала его перевели на домашнее проживание «как положительно характеризующегося осужденного», а затем и вовсе освободили [1].

И последний персонаж - бывший мэр г. Усолье-Сибирское Е.С. Кустос, обвиненный сначала в организации убийства, переквалифицированного позднее на более мягкую статью: подстрекательство к убийству. Следствие решило, что Е.С. Кустос на основе личной неприязни к генеральному директору ОАО «Молоко» Игорю Вострикову в 2002 г. заказал его убийство В. Белодедову. Однако о подготовке преступления были извещены правоохранительные органы, которые задержали несостоявшихся наемных убийц. У них изъяли револьвер с почему-то спиленным бойком, как доказательство серьезности намерений. Как и в случае с усть-илимским мэром задержанный не открыл имя заказчика убийства. Но в 2011 г. вдруг решил рассказать всю правду, указав на Е.С. Кустоса, как инициатора этого преступления.

Казалось бы, история обычная, из сферы, в которой экономические споры решаются во внесудебном, криминальном порядке. Однако, при 
более глубоком анализе ситуации, появляется предположение опять же в политической составляющей этого дела. В нулевые годы XXI в. усольский мэр был хорошо известен, как харизматичный, волевой и не ангажированный руководитель, очень популярный в своем городе. Достаточно отметить, что в 2009 г., созданное им движение «Усольчане» на выборах в городскую думу получило одиннадцать мест из двадцати, тогда как безраздельно властвовавшая на просторах страны «Единая Россия», смогла получить только три голоса [6]. Как и мэрам Иркутска, Братска, Усть-Илимска ему последовало приглашение о вступлении в партию «Единая Россия». Теперь уже сити-менеджер Е. Кустос отказался, заявив, что «глава администрации не должен заниматься политикой, он должен руководить городским хозяйством и экономикой» [6]. После этого проводится масштабная кампания по дискредитации Е. Кустоса, в которой задействованы бывшие партнеры его семейного бизнеса и апофеозом действа стало обвинение в подстрекательстве к заказному убийству.

В июне 2013 г. Верховный суд РФ оправдал чиновника по двум из трех эпизодам - незаконное хранение боеприпасов и превышение должностных полномочий. А самую тяжкую статью переквалифицировал - теперь Е. Кустос не организатор покушения на убийство, а подстрекатель. Итого - срок отбывания сократили с 10 до 8 лет, а штраф в 50 тыс. р. и вовсе отменили [1].

Подводя итог сказанному, нужно признать неоднозначность решений, принимаемых российскими судами в отношении мэров, наличие серьезных проблем с доказательной базой большинства преступлений, инкриминируемых руководителям муниципальных образований, и возможное наличие заказа со стороны политических и экономических конкурентов.

\section{Список использованной литературы и источников}

1. Лобан Е. «Курортная» зона: в каких условиях отбывают срок иркутские VIP-заключенные / Е. Лобан // Аргументы и фракты в Иркутске. - 2013. - 4 сент.

2. Мэр Казачинско-Ленского района и его зам получили 4 года колонии за взятку // Областная. - 2019. - 4 февр.

3. Переломова Ю. Голодный расчет. Мэр Ангарска решил добавить нотку трагичности в конфрликт с прокурором / Ю. Переломова // ВСП-Конкурент. 2013. -28 окт.

4. Переломова Ю. «Приговор действительно неожиданный» Экс-мэр Братска А.В. Серов получил 5,5 года строгого режима / Ю. Переломова // ВСП-Конкурент. - 2014. - 22 апр.

5. Платова Г. «Я не сдался, я буду бороться». Мэр Братска остается в застенках / Г. Платова // Советская Россия. - 2011. - 3 марта.

6. Ролдугин О. За что хотят посадить мэра Усолья? / О. Ролдугин // Собеседник. - 2012. - 7 фревр.

7. Солоненко С. Мэр на нарах / С. Солоненко // Пятница. - 2009. - 31 мая. 
8. Сочнев А. Страна посаженных мэров [Электронный ресурс] / А. Сочнев // Медиа-издание «Русская планета». - 2013. - 21 июня. - Режим доступа : http://rusplt.ru/policy/meri_needro.html\#.

9. Фомина Л. Без срока давности / Л. Фомина // ВСП-Конкурент. — 2009. — 27 июля.

10. Шинкарюк Ю. Адвокат Ташкинова: Мэр - «расстрельная» должность [Электронный ресурс] / Ю. Шинкарюк // ИА «Ирсити». - 2017. - 4 сент. - Режим доступа : https://ircity.ru/articles/23183/.

11. Экс-мэр Ангарска Жуков: Ерощенко имел все основания желать моего устранения [Электронный ресурс] // ИА «БАЙКАЛПОСТ». - 2015. - 30 июня. Режим доступа : https://ircity.ru/articles/6120/.

12. Экс-мэр Усть-Илимска предстанет перед судом за откаты на 11 млн рублей [Электронный ресурс] // РИА «ВИА». - 2016. - 11 апр. - Режим доступа : https://tayga.info/126818.

\section{Информация об авторе}

Волосов Евгений Николаевич - доктор исторических наук, декан факультета сервиса на транспорте, Иркутский филиал Московского государственного технического университета гражданской авиации, 664047, г. Иркутск, ул. Коммунаров, 3; e-mail: volosov@rambler.ru

\section{Author}

Evgeny N. Volosov - Doctor of History, Dean of the Faculty of Transport Service, Irkutsk branch of Moscow State Technical University of Civil Aviation, 3 Kommunarov St., 664047, Irkutsk, Russia; e-mail: volosov@rambler.ru 